\title{
Three Indonesian Clusters of H5N1 Virus Infection in 2005
}

\author{
I. Nyoman Kandun, M.D., M.P.H., Hariadi Wibisono, M.D., Ph.D., M.P.H., \\ Endang R. Sedyaningsih, M.D., D.P.H., Yusharmen, M.D., \\ Widarso Hadisoedarsuno, M.D., Wilfried Purba, D.V.M., M.P.H., \\ Hari Santoso, M.Epid., Chita Septiawati, M.D., Erna Tresnaningsih, M.D., Ph.D., \\ Bambang Heriyanto, M.Epid., Djoko Yuwono, M.S., Syahrial Harun, M.S., \\ Santoso Soeroso, M.D., M.H.A., Sardikin Giriputra, M.D., M.H.A., \\ Patrick J. Blair, Ph.D., Andrew Jeremijenko, M.B., B.S., M.H.A., \\ Herman Kosasih, M.D., Shannon D. Putnam, Ph.D., Gina Samaan, M.App.Epid., \\ Marlinggom Silitonga, M.D., M.Epid., K.H. Chan, Ph.D., Leo L.M. Poon, Ph.D., \\ Wilina Lim, M.D., Alexander Klimov, Ph.D., D.Sc., Stephen Lindstrom, Ph.D., \\ Yi Guan, M.D., Ph.D., Ruben Donis, Ph.D., Jacqueline Katz, Ph.D., \\ Nancy Cox, Ph.D., Malik Peiris, D.Phil., M.D., \\ and Timothy M. Uyeki, M.D., M.P.H.
}

\section{ABSTRACT}

\section{BACKGROUND}

From the Directorate General of Disease Control and Environmental Health (I.N.K., H.W., Y., W.H., W.P., H.S., C.S.) and the National Institute of Health Research and Development (E.R.S., E.T., B.H., D.Y., S.H.), Ministry of Health, Jakarta; the Infectious Disease Hospital Rumah Sakit Penyakit Infeksi Sulianti Saroso, North Jakarta (S.S., S.G.); the U.S. Naval Medical Research Unit 2, Jakarta (P.J.B., A.J., H.K. S.D.P.); and the World Health Organization, Jakarta (G.S., M.S.) - all in Indonesia; the University of Hong Kong (K.H.C. L.L.M.P., Y.G., M.P.) and the Department of Health (W.L.) - both in Hong Kong; and the Centers for Disease Control and Prevention, Atlanta (A.K., S.L., R.D., J.K., N.C., T.M.U.). Address reprint requests to Dr. Uyeki at the Influenza Division, Mail Stop A-32, Centers for Disease Control and Prevention, Atlanta, GA 30333, or at tuyeki@cdc.gov.

N EnglJ Med 2006;355:2186-94. Copyright $\odot 2006$ Massachusetts Medical Society.
Since 2003, the widespread ongoing epizootic of avian influenza A (H5N1) among poultry and birds has resulted in human H5N1 cases in 10 countries. The first case of H5N1 virus infection in Indonesia was identified in July 2005.

\section{METHODS}

We investigated three clusters of Indonesian cases with at least two ill persons hospitalized with laboratory evidence of H5N1 virus infection from June through October 2005. Epidemiologic, clinical, and virologic data on these patients were collected and analyzed.

\section{RESULTS}

Severe disease occurred among all three clusters, including deaths in two clusters. Mild illness in children was documented in two clusters. The median age of the eight patients was 8.5 years (range, 1 to 38). Four patients required mechanical ventilation, and four of the eight patients (50\%) died. In each cluster, patients with H5N1 virus infection were members of the same family, and most lived in the same home. In two clusters, the source of $\mathrm{H} 5 \mathrm{~N} 1$ virus infection in the index patient was not determined. Virus isolates were available for one patient in each of two clusters, and molecular sequence analyses determined that the isolates were clade $2 \mathrm{H} 5 \mathrm{~N} 1$ viruses of avian origin.

\section{CONCLUSIONS}

In 2005 in Indonesia, clusters of human infection with clade 2 H5N1 viruses included mild, severe, and fatal cases among family members. 
T HE AVIAN INFLUENZA A (H5N1) EPIZOotic has resulted in sporadic human cases and case clusters. Previously, H5N1 case clustering was observed in cousins in $1997^{1}$ and in a father and son in 2003. ${ }^{2} \mathrm{H} 5 \mathrm{~N} 1$ clustering was described in 2004-2005 but without sufficient information to assess whether human-to-human transmission had occurred. ${ }^{3}$ Although only one likely instance of limited human-to-human transmission of H5N1 virus was detailed in Thailand in $2004,{ }^{4}$ the investigation of case clusters is critically important, since an increase in clusters could suggest greater transmissibility of $\mathrm{H} 5 \mathrm{~N} 1$ viruses.

Since 2003, H5N1 outbreaks in poultry have occurred throughout Indonesia. ${ }^{5-7}$ Indonesia's first human H5N1 case was confirmed in July 2005, and three clusters were noted among H5N1 cases through October 2005. In this report, we describe the epidemiologic, clinical, and virologic findings of the three $\mathrm{H} 5 \mathrm{~N} 1$ case clusters.

\section{METHODS}

EPIDEMIOLOGIC AND CLINICAL INVESTIGATION

After notification of a suspected case of H5N1, the Ministry of Health in Indonesia initiated an investigation with the assistance of public health authorities and the World Health Organization (WHO). Investigators collected nasal and throat swabs, tracheal aspirates (if available), and serum specimens from patients who were suspected of having the disease; all specimens were tested for the presence of $\mathrm{H} 5 \mathrm{~N} 1$ virus. Laboratory evidence of $\mathrm{H} 5 \mathrm{~N} 1$ was defined as virus isolation or detection of H5N1 viral RNA by testing of respiratory specimens or serologically by detection of H5N1 neutralizing antibodies. Cases were classified as suspected, probable, or confirmed H5N1 virus infection, according to WHO definitions. ${ }^{8}$

We collected epidemiologic and clinical data for patients with confirmed $\mathrm{H} 5 \mathrm{~N} 1$ virus infection and their contacts through interviews and a review of medical records. Contacts of patients with H5N1 infection were followed for illness. Environmental, poultry, and other avian specimens, if available, were tested for H5N1 virus. Clinical, epidemiologic, and laboratory data were analyzed with the use of descriptive statistics. We defined a cluster of H5N1 cases as consisting of at least two persons who had disease with laboratory evidence of H5N1 virus among household members, rela- tives, or other contacts. This study was part of an ongoing public health investigation of outbreaks of H5N1 virus infection and was determined by the Ministry of Health to be exempt from approval from institutional review boards in Indonesia.

\section{LABORATORY INVESTIGATION}

Indonesian laboratories screened clinical specimens from patients with suspected H5N1 infection for the virus. Respiratory and serum specimens were shipped frozen to WHO H5 Reference Laboratories for H5N1 testing by real-time reversetranscriptase polymerase chain reaction (RT-PCR), viral culture, molecular sequencing, antiviral resistance testing, microneutralization, and Western blot analyses (see the Supplementary Appendix, available with the full text of this article at www. nejm.org).

\section{RESULTS}

Among eight previously healthy patients in three unrelated clusters, there were seven confirmed cases of $\mathrm{H} 5 \mathrm{~N} 1$ virus infection and one probable case (Fig. 1). The median age of the patients was 8.5 years (range, 1 to 38), and four of the eight patients (50\%) died, including two adults and two children.

\section{CLUSTER I}

This cluster included three of five family members living together in a suburb west of Jakarta. Patient $1 \mathrm{~A}$, an 8-year-old girl in whom fever, headache, nausea, vomiting, and rhinorrhea developed, was hospitalized with pneumonia 6 days after the onset of symptoms. She was treated with albuterol, fluticasone, ceftriaxone, meropenem, ciprofloxacin, vancomycin, gentamicin, amikacin, linezolid, and mechanical ventilation for respiratory failure, but she died on the 26th day of illness. Serum specimens collected late in her illness showed evidence of acute $\mathrm{H} 5 \mathrm{~N} 1$ virus infection on microneutralization assay.

Patient $1 \mathrm{~B}$ was a 1-year-old girl in whom fever developed 1 week after the onset of illness in her sister (Patient 1A). On the ninth day of illness, Patient $1 \mathrm{~B}$ was hospitalized with fever, rhinorrhea, cough, diarrhea, and vomiting, and she received the diagnosis of pneumonia. She was placed on mechanical ventilation but died on the 12th day of illness. No specimens were available for H5N1 testing. 


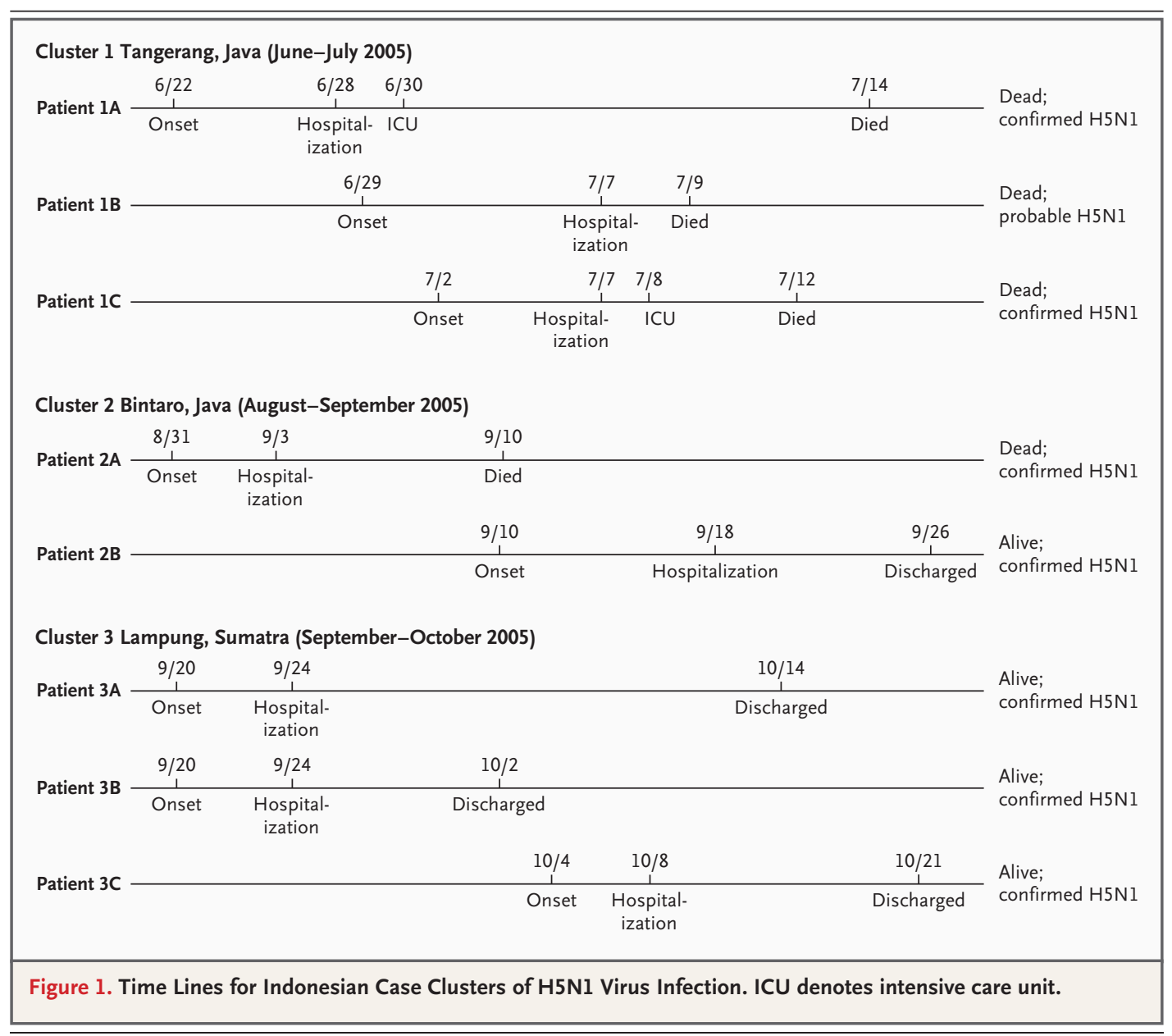

Patient 1C, who worked as a government auditor, was the 38-year-old father of Patients $1 \mathrm{~A}$ and $1 B$. He had close contact with his sick daughters at home and during their hospitalizations. He had onset of fever 3 and 9 days, respectively, after the onset of his daughters' illnesses. On the seventh day of illness, he was hospitalized with pneumonia and was treated with albuterol, budesonide, aminophylline, dexamethasone, meropenem, ceftriaxone, and linezolid. Despite mechanical ventilation, he died on the 11th day of illness. H5N1 virus was isolated from a throat swab collected on day 7.

The three patients in cluster 1 reported having had no contact with poultry, wild birds, other animals, or any sick persons besides family members before the onset of illness. Family members shared a bed after the onset of illness and before hospitalization. Patient 1C's wife, son, and two housekeepers living in the home remained well. Of the 173 contacts who were followed for 2 weeks
(8 household members and neighbors, 143 health care workers, and 22 coworkers), no other ill persons were identified.

\section{CLUSTER 2}

This cluster included two relatives living near south Jakarta. On August 31, fever, rhinorrhea, and cough developed in a 37-year-old woman (Patient 2A). On the seventh day of illness, she was hospitalized with fever, shock, and respiratory failure requiring mechanical ventilation. Methylprednisolone, levofloxacin, and meropenem were administered, and oseltamivir was given on the 10th day of illness. She died 11 days after the onset of illness; H5N1 virus was isolated from tracheal aspirate.

Patient 2B was a 9-year-old boy who lived temporarily with Patient 2A (his aunt) during her illness. Three days after his aunt was hospitalized, he had onset of fever. He was hospitalized on the ninth day of illness, with persistent fever, sore throat, and tachypnea. No supplemental oxygen, 
antibiotics, or antiviral treatment was administered, and his fever resolved on the 10th day of illness. The presence of $\mathrm{H} 5 \mathrm{~N} 1$ virus was confirmed by RT-PCR in respiratory specimens obtained on the fourth day of illness.

Patients $2 \mathrm{~A}$ and $2 \mathrm{~B}$ did not report having had contact with poultry, wild birds, other animals, or other ill persons, but chickens died nearby, and poultry were slaughtered daily approximately $50 \mathrm{~m}$ from the home. In her home garden, Patient 2A used fertilizer containing poultry feces that tested positive for H5N1 by RT-PCR. Of the 132 contacts of Patients 2A and 2B (76 household members and neighbors and 56 health care workers), no other ill persons were identified.

\section{CLUSTER 3}

Three relatives living in the same rural village in southern Sumatra made up the third cluster. In mid-September 2005, backyard chickens started dying in the village. Three days after holding two dead chickens, Patient 3A, a 21-year-old man with a history of smoking cigarettes, had an onset of fever, chills, rhinorrhea, cough, and headache. On the fifth day of illness, he was hospitalized with pneumonia and treated with ceftriaxone. Oseltamivir was started on the seventh day of illness. One week later, his respiratory status worsened, requiring supplemental oxygen, and a pleural effusion was noted on chest radiography. His condition improved, and he was discharged on day 25 of illness. A throat swab that was collected on admission tested positive for H5N1 by RT-PCR. H5N1 virus was isolated from a lung specimen obtained from a chicken close to the home.

Patient 3B, the 5-year-old brother of Patient 3A, had an onset of illness (fever, rhinorrhea, and cough) on the same day as Patient 3A, was hospitalized on the fifth day of illness, recovered without treatment, and was discharged 9 days later. Serologic confirmation of H5N1 virus infection was made more than 3 months later for Patient 3B. Patient $3 \mathrm{C}$ was the 4-year-old son of a sister of Patient 3A and Patient 3B. He lived in a separate home and did not have contact with his uncles during their illnesses but moved to their home after they were hospitalized. Patient 3C did not have any known contact with ill persons or with sick or dead poultry, but his mother had handled dead chickens and buried them. On October 4, fever, rhinorrhea, and dry cough developed in $\mathrm{Pa}$ tient 3C, but the fever lasted only 2 days. After a throat specimen tested positive for $\mathrm{H} 5 \mathrm{~N} 1$ by RT-PCR, he was hospitalized on day 5 and treatment with oseltamivir was started. A chest radiograph on day 7 revealed mild bilateral perihilar and interstitial infiltrates. He remained afebrile, received oseltamivir for 7 days, and was discharged 17 days after the onset of illness. Of the 33 household and neighborhood contacts that were followed for 2 weeks, all others remained well.

\section{CLINICAL FINDINGS}

The median time from the onset of illness to hospitalization was 7 days (range, 5 to 9) (Table 1). All patients with fatal disease presented with fever, bilateral pneumonia, and respiratory distress, and three patients presented with leukopenia, lymphopenia, and moderate thrombocytopenia. In all five patients with severe disease, including four who required mechanical ventilation, hypoxemia or hypoxia either was present on admission or developed later, requiring supplemental oxygen. None of the three mild cases required supplemental oxygen. Patients 2B and 3C had normal leukocyte, lymphocyte, and platelet counts on admission and had fever for 2 and 10 days, respectively. Only Patients $2 \mathrm{~A}, 3 \mathrm{~A}$, and $3 \mathrm{C}$ received treatment with oseltamivir, beginning on illness days 10,7 , and 5 , respectively. Six patients received antibiotics to treat possible bacterial coinfection, but no invasive bacterial infections were identified.

Of six patients whose serum albumin levels were measured either at or close to their hospital admission, four patients with fatal disease had hypoalbuminemia (albumin range, 2.2 to $3.1 \mathrm{~g}$ per deciliter). One patient with severe but nonfatal disease had an albumin level of $2.4 \mathrm{~g}$ per deciliter, and one patient with very mild disease had a level of $4.3 \mathrm{~g}$ per deciliter. Four patients with severe disease had moderately elevated levels of aspartate aminotransferase and alanine aminotransferase, with levels of aspartate aminotransferase higher than those of alanine aminotransferase, at or shortly after admission, as compared with one patient with mild disease who had normal levels.

\section{H5NI TESTING}

H5N1 virus was isolated from a throat swab from Patient $1 \mathrm{C}$ on illness day 7 and from a tracheal aspirate from Patient 2A on day 10 (Table 2). Molecular sequencing of $\mathrm{H} 5 \mathrm{~N} 1$ viruses isolated from Patient 1C (A/Indonesia/5/2005) and Patient 2A 


\begin{tabular}{|c|c|c|c|c|c|c|c|c|c|c|c|}
\hline \multirow[t]{3}{*}{$\begin{array}{l}\text { Patient } \\
\text { No. }\end{array}$} & Age & Sex & $\begin{array}{c}\text { Chronic } \\
\text { Conditions }\end{array}$ & $\begin{array}{l}\text { Day of Illness } \\
\text { at Hospital } \\
\text { Admission }\end{array}$ & $\begin{array}{l}\text { Symptoms } \\
\text { and Signs }\end{array}$ & \multicolumn{6}{|c|}{ Findings on Admission } \\
\hline & & & & & & Temperature & $\begin{array}{l}\text { Respiratory } \\
\text { Rate }\end{array}$ & $\begin{array}{l}\text { Total White- } \\
\text { Cell Count }\end{array}$ & $\begin{array}{l}\text { Absolute } \\
\text { Lymphocyte } \\
\text { Count }\end{array}$ & $\begin{array}{l}\text { Platelet } \\
\text { Count }\end{array}$ & $\begin{array}{c}\text { Chest } \\
\text { Radiography }\end{array}$ \\
\hline & $y r$ & & & & & ${ }^{\circ} \mathrm{C}$ & breaths/min & percl & cubic millimete & & \\
\hline $1 \mathrm{~A}$ & 8 & $\mathrm{~F}$ & None & 7 & $\begin{array}{l}\text { Fever, } 7 \text { days; } \\
\text { cough, head- } \\
\text { ache, nausea, } \\
\text { vomiting }\end{array}$ & 38 & 40 & 1780 & 445 & 185,000 & $\begin{array}{l}\text { Bilateral in- } \\
\quad \text { filtrates }\end{array}$ \\
\hline 1B & 1 & $\mathrm{~F}$ & None & 7 & $\begin{array}{l}\text { Fever, } 7 \text { days; } \\
\text { cough, } 2 \text { days; } \\
\text { rhinorrhea } \\
\text { and diarrhea, } \\
3 \text { days; dys- } \\
\text { pnea, } 1 \text { day }\end{array}$ & 38.8 & 25 & 4200 & NA & 221,000 & $\begin{array}{l}\text { Bilateral in- } \\
\text { filtrates }\end{array}$ \\
\hline 1C & 38 & M & $\begin{array}{l}\text { History of } \\
\text { cigarette } \\
\text { smoking }\end{array}$ & 7 & $\begin{array}{l}\text { Fever, cough, } \\
\text { shortness of } \\
\text { breath, diffi- } \\
\text { culty breath- } \\
\text { ing, abdomi- } \\
\text { nal pain }\end{array}$ & 39.3 & 34 & 2310 & NA & 146,000 & $\begin{array}{l}\text { Bilateral in- } \\
\text { filtrates }\end{array}$ \\
\hline $2 A$ & 37 & $\mathrm{~F}$ & None & 7 & $\begin{array}{l}\text { Fever, } 7 \text { days; } \\
\text { rhinorrhea, } \\
\text { cough, short- } \\
\text { ness of breath, } \\
\text { hypotension }\end{array}$ & 39 & 42 & 2980 & NA & 208,000 & $\begin{array}{l}\text { Bilateral in- } \\
\quad \text { filtrates }\end{array}$ \\
\hline $2 B$ & 9 & M & None & 9 & $\begin{array}{l}\text { Fever, } 9 \text { days; } \\
\text { sore throat }\end{array}$ & 38.8 & 34 & 7600 & 2356 & 313,000 & Not done \\
\hline $3 \mathrm{~A}$ & 21 & M & $\begin{array}{l}\text { History of } \\
\text { cigarette } \\
\text { smoking }\end{array}$ & 5 & $\begin{array}{l}\text { Fever, cough, } \\
5 \text { days }\end{array}$ & 38.3 & 48 & 5000 & 850 & 145,000 & $\begin{array}{l}\text { Bilateral in- } \\
\text { filtrates }\end{array}$ \\
\hline 3B & 5 & M & None & 5 & $\begin{array}{l}\text { Fever, rhinor- } \\
\text { rhea, cough, } \\
\text { headache, } \\
5 \text { days }\end{array}$ & NA & NA & 2900 & 1421 & 138,000 & Not done \\
\hline $3 C$ & 4 & M & None & 5 & $\begin{array}{c}\text { Fever, rhinorrhea, } \\
\text { cough, } 2 \text { days; } \\
\text { all symptoms } \\
\text { resolved } 3 \\
\text { days before } \\
\text { admission }\end{array}$ & 37 & 30 & 7600 & 4256 & 373,000 & $\begin{array}{l}\text { Mild bilater- } \\
\text { al inter- } \\
\text { stitial } \\
\text { and peri- } \\
\text { hilar infil- } \\
\text { trates }\end{array}$ \\
\hline
\end{tabular}

* NA denotes not available.

(A/Indonesia/6/2005) indicated that both $\mathrm{H} 5 \mathrm{~N} 1$ vi- idase inhibitors found that both $\mathrm{H} 5 \mathrm{~N} 1$ viruses ruses were of the $Z$ genotype. In addition, all eight were sensitive to such agents. Of the five patients genes of both H5N1 viruses were of avian origin whose disease was confirmed by RT-PCR, the same and were clade 2 viruses, as defined previously. ${ }^{9}$ specimens tested negative by rapid antigen testing. Both A/Indonesia/5/2005 and A/Indonesia/6/2005 Throat swabs had a higher yield for detection of had M2 gene sequences, indicating susceptibility H5N1 virus by RT-PCR assay and viral isolation to adamantanes. Sequencing of the neuraminidase than did nasal swabs. A throat swab from Patient genes and assaying for susceptibility to neuramin- 3B was positive on RT-PCR assay on illness day 8, 


\begin{tabular}{|c|c|c|c|c|c|}
\hline $\begin{array}{l}\text { Maximum } \\
\text { Temperature }\end{array}$ & $\begin{array}{l}\text { Mechanical } \\
\text { Ventilation }\end{array}$ & $\begin{array}{l}\text { Oseltamivir } \\
\text { Treatment }\end{array}$ & $\begin{array}{c}\text { Corticosteroid } \\
\text { Therapy }\end{array}$ & $\begin{array}{l}\text { Time from } \\
\text { Onset to Death } \\
\text { or Discharge }\end{array}$ & Outcome \\
\hline${ }^{\circ} \mathrm{C}$ & & & & days & \\
\hline 39.2 & $\begin{array}{c}\text { Yes (on hospital day } \\
2 \text {, illness day 8) }\end{array}$ & No & Yes & 22 & Death \\
\hline 38.8 & $\begin{array}{r}\text { Yes (on hospital day } \\
2 \text {, illness day } 11 \text { ) }\end{array}$ & No & Yes & 8 & Death \\
\hline 40.0 & $\begin{array}{l}\text { Yes (on admission, } \\
\text { illness day } 7 \text { ) }\end{array}$ & No & Yes & 11 & Death \\
\hline 41.0 & $\begin{array}{l}\text { Yes (on admission, } \\
\text { illness } \\
\text { day } 7 \text { ) }\end{array}$ & $\begin{array}{c}\text { Yes (on illness day } \\
\text { 10, started on } 75 \\
\text { mg twice daily } \\
\text { orally for } 1 \text { day) }\end{array}$ & Yes & 11 & Death \\
\hline 38.8 & No & No & No & 17 & Recovery \\
\hline 38.3 & No & $\begin{array}{c}\text { Yes (on illness day } \\
7 \text {, started on } 75 \\
\text { mg twice daily } \\
\text { orally for } 5 \text { days) }\end{array}$ & Yes & 25 & Recovery \\
\hline NA & No & No & No & 14 & Recovery \\
\hline 37.0 & No & $\begin{array}{c}\text { Yes (on illness day } \\
5 \text {, started on } 35 \\
\text { mg twice daily } \\
\text { orally for } 7 \text { days) }\end{array}$ & No & 17 & Recovery \\
\hline
\end{tabular}

even though the patient had fever for only 2 days and began receiving oseltamivir on day 5 .

\section{DISCUSSION}

Our study documents clusters of clade 2 H5N1 virus infection among Indonesian families. These findings and other reports of clusters among family members and relatives in Hong Kong, Vietnam, Thailand, China, Azerbaijan, and Turkey ${ }^{1-4,10-14}$ raise questions as to whether genetic or other factors may predispose some persons to $\mathrm{H} 5 \mathrm{~N} 1$ virus infection or to severe disease. Since the completion of this investigation, additional H5N1 case clusters have been identified in Indonesia, including a large cluster in northern Sumatra in May 2006. WHO recommends close follow-up and oseltamivir chemoprophylaxis for household members and relatives of patients with $\mathrm{H} 5 \mathrm{~N} 1$ virus infection who had close contact either with the pa- 


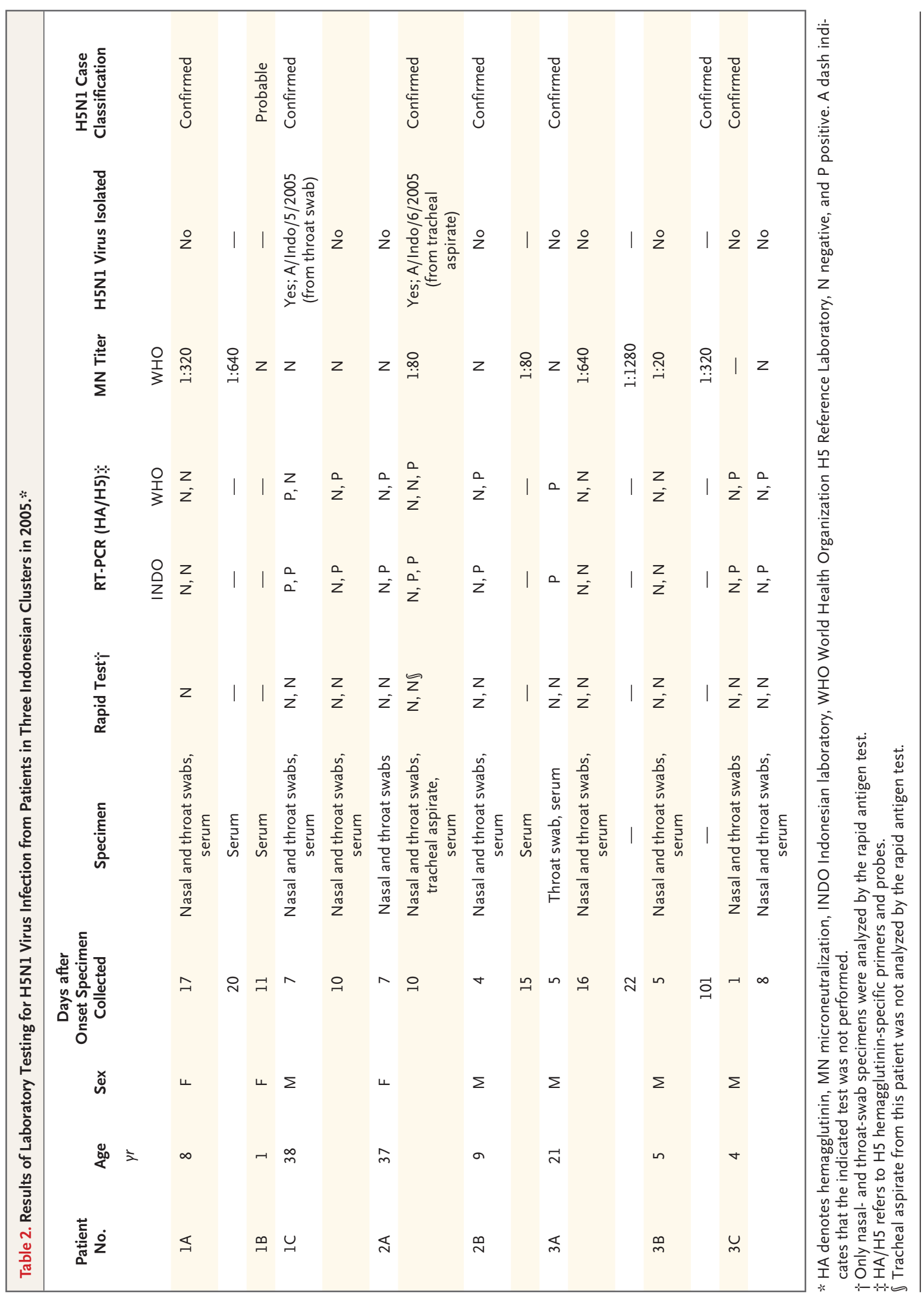


tient with the disease or with sick or dead poultry. ${ }^{15}$ Prompt antiviral treatment of any associated identified ill persons is also recommended.

We identified three pediatric patients with clinically mild disease in two clusters. This finding is consistent with data from 1997, when most pediatric patients with $\mathrm{H} 5 \mathrm{~N} 1$ virus infection in Hong Kong had relatively mild disease. ${ }^{16,17}$ Another study identified mild and asymptomatic H5N1 virus infection in two adult health care workers in 1997.18 Identification of three mild $\mathrm{H} 5 \mathrm{~N} 1$ cases in this study and one case in Turkey (as reported by Oner et al. ${ }^{12}$ elsewhere in this issue of the Journal) has implications for surveillance, since most H5N1 case findings have focused on patients who were hospitalized with severe pneumonia.

We were not able to determine the source of H5N1 virus infection for the index patients in two clusters, and transmission through contact with environmentally contaminated material remains a possibility. In the first cluster, a caged bird with H5N1 virus infection near the home suggested the possibility of environmental contamination with H5N1 virus, although no virus was detected around the residence. The index patient in the second cluster could have acquired infection through contact with fertilizer containing H5N1-contaminated poultry feces. The presence of a poultry-slaughtering operation approximately $50 \mathrm{~m}$ from the home and dead chickens in the neighborhood also suggests that $\mathrm{H} 5 \mathrm{~N} 1$ environmental contamination could have been a source.

Limited person-to-person H5N1 transmission could not be excluded in two clusters among patients who had no known contact with poultry or other animals. Although Patient 1B was not tested, her clinical characteristics and evidence that her sister (Patient 1A) and her father had acute H5N1 virus infection all strongly suggest she also had $\mathrm{H} 5 \mathrm{~N} 1$ virus infection. Both Patient $1 \mathrm{~B}$ and her father had close contact with Patient 1A before their illnesses. Similarly, the only identified exposure for Patient 2B was close contact with his aunt (Patient 2A) during her illness. Limited, nonsustained H5N1 virus transmission from Patient $1 \mathrm{~A}$ to her sister and father, from Patient $1 \mathrm{~B}$ to her father, and from Patient 2A to her nephew remain possible explanations given the epidemiologic investigation.

As compared with nasal swabs, throat specimens provided the highest yield for the detection of H5N1 virus. Rapid antigen testing did not detect any $\mathrm{H} 5 \mathrm{~N} 1$ cases, which is consistent with data reported for clade 1 infections ${ }^{19}$ and supports guidance against using such tests for the detection of $\mathrm{H} 5 \mathrm{~N} 1$ virus. $^{20}$

Few Indonesian patients with clade $2 \mathrm{H} 5 \mathrm{~N} 1$ virus infection in these clusters had diarrhea, unlike patients with clade $1 \mathrm{H} 5 \mathrm{~N} 1$ virus infection. ${ }^{19,21,22}$ Most patients with $\mathrm{H} 5 \mathrm{~N} 1$ virus infection had hypoalbuminemia at or close to the time of hospital admission, which has not been reported previously. Whether this finding is related to viral, renal, hepatic, gastrointestinal, iatrogenic, or other factors is unknown. The effects of corticosteroid therapy or late oseltamivir treatment could not be determined. Both $\mathrm{H} 5 \mathrm{~N} 1$ clade 2 viral isolates were sensitive to adamantanes and neuraminidase inhibitors, although adamantanes are not recommended by the WHO owing to a high frequency of $\mathrm{H} 5 \mathrm{~N} 1$ viruses that are resistant to amantadine and rimantadine. ${ }^{15}$ Resistance to oseltamivir has been reported in patients with clade $1 \mathrm{H} 5 \mathrm{~N} 1$ virus infection. ${ }^{13,14} \mathrm{~A}$ recent study showed a correlation between a high H5N1 viral load and hypercytokinemia, and the investigators concluded that early antiviral treatment is needed to suppress viral replication and to prevent the overwhelming inflammatory response implicated in $\mathrm{H} 5 \mathrm{~N} 1$ pathogenesis. $^{23}$ Therefore, much more research is needed to define optimal treatment for patients with H5N1 virus infection.

Our findings of a wide range of clinical features and outcomes associated with clade $2 \mathrm{H} 5 \mathrm{~N} 1$ virus infection in Indonesia highlight the importance of careful clinical examination, laboratory diagnosis, and sequential monitoring of all patients with suspected $\mathrm{H} 5 \mathrm{~N} 1$ virus infection and their close contacts. Further research is needed to understand the role of mild cases in the epidemiology of this disease and whether genetic, behavioral, immunologic, and environmental factors may contribute to case clustering of $\mathrm{H} 5 \mathrm{~N} 1$ virus infection.

All authors report receiving financial support from their respective institutions. No potential conflict of interest relevant to this article was reported.

The views expressed in this article are those of the authors and do not reflect the official policy or position of the Indonesian National Institute of Health Research and Development and Directorate General of Disease Control and Environmental Health (Ministry of Health), the U.S. Department of Defense, the U.S. Department of the Navy, or the Centers for Disease Control and Prevention (CDC).

We thank our many colleagues at the Directorate General of Disease Control and Environmental Health and the National In- 
stitute of Health Research and Development, Ministry of Health, Jakarta; the provincial, district, and subdistrict health offices; the health care providers at Indonesian hospitals who cared for patients with H5N1 virus infection; the U.S. Naval Medical Re- search Unit 2; the WHO in Indonesia; Hong Kong University; Hong Kong Government Virus Unit; and the CDC, for their contributions to our epidemiologic, clinical, virologic, and immunologic investigations.

REFERENCES

1. Isolation of avian influenza A(H5N1) viruses from humans - Hong Kong, MayDecember 1997. MMWR Morb Mortal Wkly Rep 1997;46:1204-7.

2. Peiris JS, Yu WC, Leung CW, et al. Reemergence of fatal human influenza A subtype H5N1 disease. Lancet 2004;363: 617-9.

3. Olsen SJ, Ungchusak K, Sovann L, et al. Family clustering of avian influenza A (H5N1). Emerg Infect Dis 2005;11:1799 801.

4. Ungchusak K, Auewarakul P, Dowell $\mathrm{SF}$, et al. Probable person-to-person trans mission of avian influenza A (H5N1) N Engl J Med 2005;352:333-40.

5. Office International des Epizooties. Highly pathogenic avian influenza in Indonesia. Jakarta, Indonesia: Department of Agriculture, February 6, 2004. (Accessed October 30, 2006, at ftp://ftp.oie.int/infos san_archives/eng/2004/en_040206v17n06. pdf.)

6. Avian influenza - situation in Indo nesia - update 32. Geneva: World Health Organization, September 29, 2005. (Accessed October 30, 2006, at http://www. who.int/csr/don/2005_09_29/en/index. html.)

7. Smith GJD, Naipospos TSP, Nguyen TD, et al. Evolution and adaptation of $\mathrm{H} 5 \mathrm{~N} 1$ influenza virus in avian and human hosts in Indonesia and Vietnam. Virology 2006;350:258-68

8. WHO case definitions for human infections with influenza A (H5N1) virus. Geneva: World Health Organization, August 29,
2006. (Accessed October 30, 2006, at http:/ www.who.int/csr/disease/avian_influenza/ guidelines/case_definition2006_08_29/en/ index.html.)

9. World Health Organization Global Influenza Program Surveillance Network. Evolution of H5N1 avian influenza viruse in Asia. Emerg Infect Dis 2005;11:1515-21.

10. Yu H, Shu Y, Hu S, et al. The first confirmed human case of avian influenza $A$ (H5N1) in Mainland China. Lancet 2006 367:84.

11. Human avian influenza in Azerbaijan, February-March 2006. Wkly Epide miol Rec 2006;81:183-8.

12. Oner AF, Bay A, Arslan S, et al. Avian influenza A (H5N1) infection in eastern Turkey in 2006. N Engl J Med 2006;355: 2179-85.

13. Le QM, Kiso M, Someya K, et al. Avian flu: isolation of drug-resistant $\mathrm{H} 5 \mathrm{~N} 1$ virus. Nature 2005;437:1108. [Erratum, Nature 2005;438:754.]

14. de Jong MD, Tran TT, Truong HK, et al. Oseltamivir resistance during treat ment of influenza A (H5N1) infection. N Engl J Med 2005;353:2667-72.

15. WHO rapid advice guidelines on phar macological management of humans in fected with avian influenza A (H5N1) virus. Geneva: World Health Organization, 2006. (Accessed October 30, 2006, at http:// www.who.int/csr/disease/avian_influenza/ guidelines/pharmamanagement/en/index. html.)

16. Chan PK. Outbreak of avian influenza $\mathrm{A}(\mathrm{H} 5 \mathrm{~N} 1)$ virus infection in Hong Kong in
1997. Clin Infect Dis 2002;34:Suppl 2:S58S64.

17. Yuen KY, Chan PK, Peiris $M$, et al. Clinical features and rapid viral diagnosis of human disease associated with avian influenza A H5N1 virus. Lancet 1998;351: 467-71.

18. Buxton Bridges C, Katz JM, Seto WH, et al. Risk of influenza A (H5N1) infection among health care workers exposed to patients with influenza A (H5N1), Hong Kong. J Infect Dis 2000;181:344-8.

19. The Writing Committee of the World Health Organization (WHO) Consultation on Human Influenza A/H5. Avian influenza A (H5N1) infection in humans. N Engl J Med 2005;353:1374-85.

20. WHO recommendations on the use of rapid testing for influenza diagnosis. Geneva: World Health Organization, July 2005. (Accessed October 30, 2006, at http:// www.who.int/csr/disease/avian_influenza/ guidelines/RapidTestInfluenza_web.pdf.) 21. Tran TH, Nguyen TL, Nguyen TD, et al. Avian influenza A (H5N1) in 10 patients in Vietnam. N Engl J Med 2004;350: 1179-88

22. Chotpitayasunondh T, Ungchusak K, Hanshaoworakul W, et al. Human disease from influenza A (H5N1), Thailand, 2004. Emerg Infect Dis 2005;11:201-9.

23. de Jong MD, Simmons CP, Thanh TT, et al. Fatal outcome of human influenza $\mathrm{A}$ (H5N1) is associated with high viral load and hypercytokinemia. Nat Med 2006;12: 1203-7.

Copyright (c) 2006 Massachusetts Medical Society. 